\title{
A Rare Presentation with Bilateral Peripheral Facial Palsy
}

\section{Bilateral Periferik Fasial Palsi ile Nadir Prezentasyon}

\author{
(1) Berrin Erok, (1) Hakan Önder \\ University of Health Sciences Turkey, Prof. Dr. Cemil Taşcıoğlu City Hospital, Clinic of Radiology, İstanbul, Turkey
}

\begin{abstract}
Acute suppurative otomastoiditis (ASOM) refers to the concurrent occurrence of suppurative acute otitis media and acute mastoiditis, occurring mostly in childhood. Complications are rare in the recent era with the development of wide spectrum antibiotics. However, when the mucoperiosteal involvement evolves into osteomyelitis $(\mathrm{OM})$, severe complications may develop. This generally occurs in immunocompromised patients or patients with some illnesses associated with decreased bone vascularity such as diabetes mellitus (DM). We report a 58-year-old male patient presenting with bilateral peripheral facial palsy in whom OM resulting from coalescent mastoiditis affected the skull base and the bilateral fallopian canals. In the management of ASOM, especially with the presence of the risk factors such as $\mathrm{DM}$, follow up imaging is important to reveal OM of the mastoid bone before it spreads to the skull base and further it is complicated with intracranial extensions. On radiological imaging, temporal computed tomography with bone algorithm is the first method of choice to reveal early bony resorptions of OM.
\end{abstract}

Keywords: Coalescent mastoiditis, cranial osteomyelitis, bilateral peripheral facial palsy

\section{$\ddot{O} \mathbf{z}$}

Akut süpüratif otomastoidit (ASOM), çoğunlukla çocukluk çağında ortaya çıkan süpüratif akut otitis media ve akut mastoiditin birlikte görülmesini ifade eder. Son dönemde geniş spektrumlu antibiyotiklerin gelişmesi ile komplikasyonlar nadirdir. Ancak, mukoperiostal tutulum osteomiyelite (OM) ilerlediğinde ciddi komplikasyonlar gelişebilir. Bu, genellikle bağışıklığı baskılanmış hastalarda veya diabetes mellitus (DM) gibi kemik vaskülaritesinde azalma ile ilişkili bazı hastalıklar olduğunda ortaya çıkar. Bu yazıda, koalesan mastoidit sonucu gelişen, kafa tabanını ve bilateral fallop kanalları etkileyen OM'ye bağlı bilateral periferik fasial palsi ile başvuran 58 yaşındaki erkek hastamızı sunuyoruz. ASOM tedavisinde, özellikle DM gibi risk faktörlerinin varlığında, takip görüntüleme mastoid kemiğin OM’sini kafa tabanına yayılmadan ve kafa içi yayılım ile komplike hale gelmeden önce ortaya çıkarmak için önemlidir. Radyolojik görüntülemede kemik algoritmalı temporal bilgisayarlı tomografi, OM'nin erken kemik rezorpsiyonlarını ortaya çıkarmak için ilk tercih edilen yöntemdir.

Anahtar Kelimeler: Koalesan mastoidit, kranial osteomiyelit, bilateral periferal fasial palsi

\section{Introduction}

Acute suppurative otomastoiditis (ASOM) refers to the concurrent occurance of suppurative acute otitis media and acute mastoiditis, seen mostly in childhood. The most common causative agents are Streptococcus pneumoniae and Haemophilus influenzae (1). Complications are rare in the recent era with the development of wide spectrum antibiotics. However, severe complications may develop. This generally occurs in immunocompromised patients or patients with some illnesses associated with decreased bone vascularity such as diabetes mellitus $(\mathrm{DM})(2,3)$. We present a complicated case of ASOM presenting with bilateral peripheral facial palsy.

\section{Case Report}

A 58-year-old male patient with type $2 \mathrm{DM}$ and severe chronic renal failure presented to our emergency department with bilateral peripheral facial palsy and otalgia. Head computed tomography revealed opacification of mastoid air cells and the tympanic cavities, bilaterally. There was resorption of the bony septa at the inferomedial parts of the bilateral mastoid bones resulting in coalescent mastoiditis. The erosive bone changes were also present at the sigmoid plates overlying the jugular bulbs and at the ventral part of the clivus, compatible with skull base osteomyelitis (SBO). The posterior genu and mastoid segments of the fallopian canals were involved in the area of coalescent mastoiditis explaining the

Address for Correspondence/Yazışma Adresi: Berrin Erok MD, University of Health Sciences Turkey, Prof. Dr. Cemil Taşcıoğlu City Hospital, Clinic of Radiology, İstanbul, Turkey

Phone: +90 2123145555 E-mail: drberinerok@hotmail.com ORCID: orcid.org/0000-0001-8036-547X

Received/Geliş Tarihi: 12.06.2021 Accepted/Kabul Tarihi: 14.11.2021

${ }^{\circ}$ Copyright 2022 by Turkish Neurological Society

Turkish Journal of Neurology published by Galenos Publishing House. 
presentation of the patient with bilateral peripheral facial palsy (Figure 1). On magnetic resonance imaging (MRI), fluid signal intensities were present within the mastoid ear cells and middle ear clefts on T2-weighted images. There were also associated inflammatory signal intensities at the right basiocciput and the ventral clivus (Figure 2). Due to the severe chronic kidney disease, gadolinium enhanced imaging could not be performed,

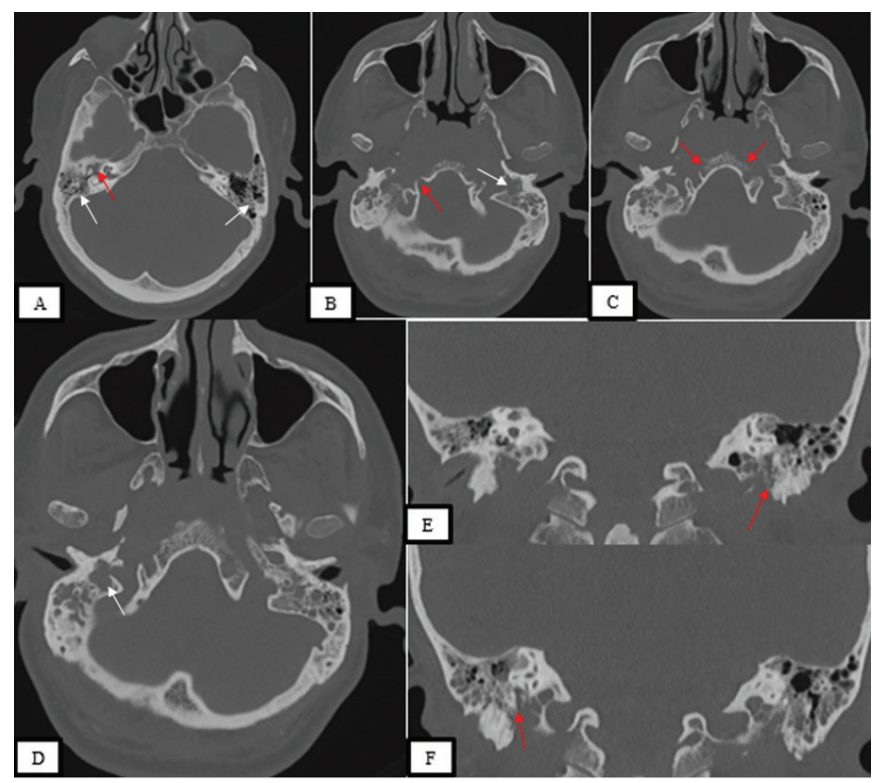

Figure 1. Axial (A, B, C, D) and coronal (E, F) temporal computed tomography images showing opacifications within the mastoid air cells, bilaterally ( $A$, white arrows), and within the right middle ear ( $A$, red arrow). Note the destruction of the sigmoid plate overlying the left jugular bulb (B, red arrow). Involvement of the ventral clivus (C, red arrows) is demonstrated. The resorption of the bony septae between the mastoid air cells at the inferomedial mastoid bone is shown (B, D, white arrow). The fallopian canals and their involved continuations within the area of coalescent mastoiditis (E, F, red arrows) are shown

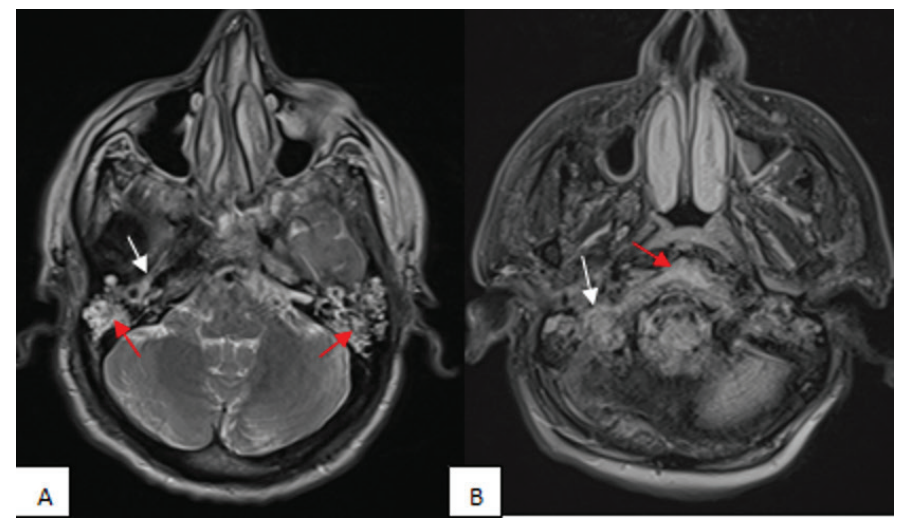

Figure 2. Non-contrast brain MRI A) axial T2w and B) axial FLAIR images showing fluid signal intensities within the mastoid air cells, bilaterally (A, red arrows), and within the right middle air cleft (A, white arrow). The inflammatory increased signal intensities at the right basiocciput ( $\mathrm{B}$, white arrow) and at the clival marrow (B, red arrow) are shown

MRI: Magnetic resonance imaging, FLAIR: Fluid-attenuated inversion recovery

266 however on non-contrast MRI, there were no signs of intracranial involvement.

\section{Discussion}

In the cranial bones, the spread of infection through the emissary veins into the periosteum (periostitis) causes the acute clinical presentation of otomastoiditis (4). This is the incipient stage of the disease limited with mucoperiosteal involvement, which may evolve into osteomyelitis $(\mathrm{OM})$ with the infiltration and resorption of the involved bones. In the mastoid bone, the destruction of the bony septae between the air cells results in coalescent mastoiditis, which is actually a radiological diagnosis referring essentially to the stage of OM (Figure 1). Presentation with peripheral facial palsy due to the involvement of the fallopian canal in otogenic infections is rare with estimated incidence of about $0.005 \%$ (5). In our patient, the mastoid segment and the posterior genu of the fallopian canals were involved in the area of the coalescent mastoiditis resulting in bilateral facial palsy, which was different from the more usual cases of the involvement of the tympanic segments due to the suppurative infections within the middle ear. Cranial OM also rarely occurs in patients with ASOM, usually as a complication of postoperative craniotomy (iatrogenic) or due to direct injury to the cranium. It may affect either the cranial vault or the skull base. In our patient, the spread of the disease from the mastoid bone to the right basiocciput and then the ventral clivus resulted in SBO. In the management of ASOM, especially with the presence of risk factors such as DM, follow up imaging is important to reveal OM of the mastoid bone before it spreads to the skull base and is further complicated with intracranial extentions.

\section{Ethics}

Informed Consent: Written consent was obtained.

Peer-review: Internally peer-reviewed.

\section{Authorship Contributions}

Concept: B.E., H.Ö., Design: B.E., Data Collection or Processing: B.E., Analysis or Interpretation: B.E., H.Ö., Literature Search: B.E., Writing: B.E.

Conflict of Interest: No conflict of interest was declared by the authors.

Financial Disclosure: The authors declared that this study received no financial support.

\section{References}

1. Atkinson H, Wallis S, Coatesworth AP. Acute otitis media. Postgrad Med 2015;127:386-390.

2. Chang PC, Fischbein NJ, Holliday RA. Central skull base osteomyelitis in patients without otitis externa: imaging findings. AJNR Am J Neuroradiol 2003;24:1310-1316.

3. Lee S, Hooper R, Fuller A, et al. Otogenic cranial base osteomyelitis: a proposed prognosis-based system for disease classification. Otol Neurotol 2008;29:666-672.

4. Vazquez E, Castellote A, Piqueras J, et al. Imaging of complications of acute mastoiditis in children. Radiographics 2003;23:359-372.

5. Ellefsen B, Bonding P. Facial palsy in acute otitis media. Clin Otolaryngol Allied Sci 1996;21:393-395. 